\title{
Relationships between allozymes, heterozygosity and morphological characters in red deer (Cervus elaphus), and the influence of selective hunting on allele frequency distributions
}

\author{
GÜNTHER B. HARTL, *§ GÉRARD LANG,† FRANÇOIS KLEIN屯 \& RUDOLF WILLING* \\ *Forschungsinstitut für Wildtierkunde der Veterinärmedizinischen Universität Wien, Savoyenstrasse 1, A-1160, Vienna, \\ Austria, $\nmid 26 a$, rue principale, 67240 Gries, France and $\ddagger$ Office National de la Chasse - CNERA Cervidés Sanglievs Au \\ Bord du Rhin, 67150 Gerstheim, France
}

\begin{abstract}
Morphological characters in red deer (Cervus elaphus), which serve as criteria for selective hunting, were examined in relation to electrophoretic variation in three populations from the Vosges in eastern France. From the polymorphic loci examined, certain alleles at $I d h-2, M e-1$ and $A c p-1$ showed significant associations with a special development of body and antler characters selected for by hunters. Idh-2 $2^{I 25}$ was associated with larger hind foot length in females and a higher number of antler points in males. $M e-1^{90}$ and $A c p-1^{100}$ were associated with small spikes. The populations studied differed from one another in the duration and intensity of selective hunting and the increase or decrease in the respective allele frequencies could be explained by selection for large body size, a high number of antler points and against small spikes in yearlings, rather than by genetic drift. Among other morphological characters examined, the length of the main beam was significantly associated with the allele $A c p-2^{100}$. In contrast, no associations could be detected between overall heterozygosity and the development or the degree of asymmetry (in paired structures) of any of the morphological traits in question. Although no obvious differences in the overall values of polymorphism or heterozygosity were found between the populations, selective hunting leads towards a change in allele frequencies and eventually to the loss of one or the other rare allele.
\end{abstract}

Keywords: allozymes, antler development, Red deer, selective hunting.

\section{Introduction}

The preservation of genetic variation within populations of free-ranging animals is currently one of the most important goals of theoretical, experimental and applied population genetics (see Schonewald-Cox et al., 1983 and Soulé, 1987 for reviews). Most attention is paid to the genetic effects of population bottlenecks, breeding in captivity and re-introduction into natural or artificially founded biotopes. In contrast, the influence of selective hunting on the genetic composition of populations of large mammals has been poorly examined by biochemical-genetic techniques (see e.g. Ryman et al., 1981).

$\S$ To whom correspondence should be addressed.
Among all large mammals subjected to selective hunting one of the most affected species is the red deer (Cervus elaphus), where selection favouring large body size, a high number of antler points and large spikes in yearlings (considered as an indicator for later 'antler quality' in adult males) was increasingly established in the hunting laws or rules of European countries such as Germany, Austria, Hungary and part of France since the 1920s (Lang, 1987; Ueckermann, 1987). The question whether the development of those characters reflects mainly environmental influences and the condition of the animals, or is largely determined by the genetic background is still under discussion (see e.g. Harmel, 1983; Suttie \& Kay, 1983; Williams et al., 1983; Marchinton et al., 1987). As enzyme hetero- 
zygosity is frequently considered to be associated with an enhanced plasticity and capacity of metabolism, individuals showing large body size and superior 'antler quality' may be more heterozygous in the first case (Soulé, 1979; Smith et al., 1983; Watt, 1985; Zouros et al., 1988; Scribner et al., 1989). On the other hand, certain alleles at enzyme loci may be associated with a particular development of body and antler traits in the second (Røed, 1987).

In this study we report evidence that, in red deer, alleles at some enzyme loci $(M e-1, I d h-2, A c p-1)$, one of them $(I d h-2)$ already found to be associated with juvenile mortality in the same species (Pemberton et al., 1988), are associated with certain development of morphological characters favoured by selective hunting. In three populations, a direct connection between the duration and intensity of selective hunting and the change in allele frequencies at the $I d h-2$ and the $A c p-1$ locus is demonstrated.

\section{Materials and methods}

Three distinct red deer populations from the Vosges in eastern France were surveyed, which differ from one another in a number of relevant parameters (Fig. 1).
The population in DON (containing about 500 individuals in 1880) is the origin of all red deer present in the Vosges. Its current population size is about 2750 individuals with an estimated $N_{\mathrm{e}}$, of 1833 (calculated using the formula $N_{\mathrm{e}}=4 N_{\mathrm{m}} N_{\mathrm{f}} /\left(N_{\mathrm{m}}+N_{\mathrm{f}}\right)$, Lucotte, 1983; assuming a sex ratio in reproduction of $1 \mathrm{~m}: 2 \mathrm{f}$, Clutton-Brock et al., 1982). Selective culling was established as late as 1976 and is practised, in part of the population, up to the present (Lang, 1987). The population in VN originates from DON and has an $N_{\mathrm{e}}$ of about 533. Gene flow between VN and DON is prevented or strongly reduced by the completely fenced Paris-Strasbourg motorway built in 1974-1976, which is proven by the search for tracks and the observation of marked individuals ( $F$. Klein, unpublished observations). Selective hunting was started in the whole population in 1971 with extreme hunting pressure against small spikes in yearlings. The JPV population was founded in 1961 with nine individuals (two males, four females, three calves) originating from VN. Assuming an annual increase in population size of 33 per cent and a generation interval of 6 years (Gaillard, personal communication), the present $N_{\mathrm{e}}$ is estimated to be 22.8 (calculated using the harmonic mean of $N_{\mathrm{e}}$ obtained for each of five generations, Lucotte, 1983). There is a high hunting pressure

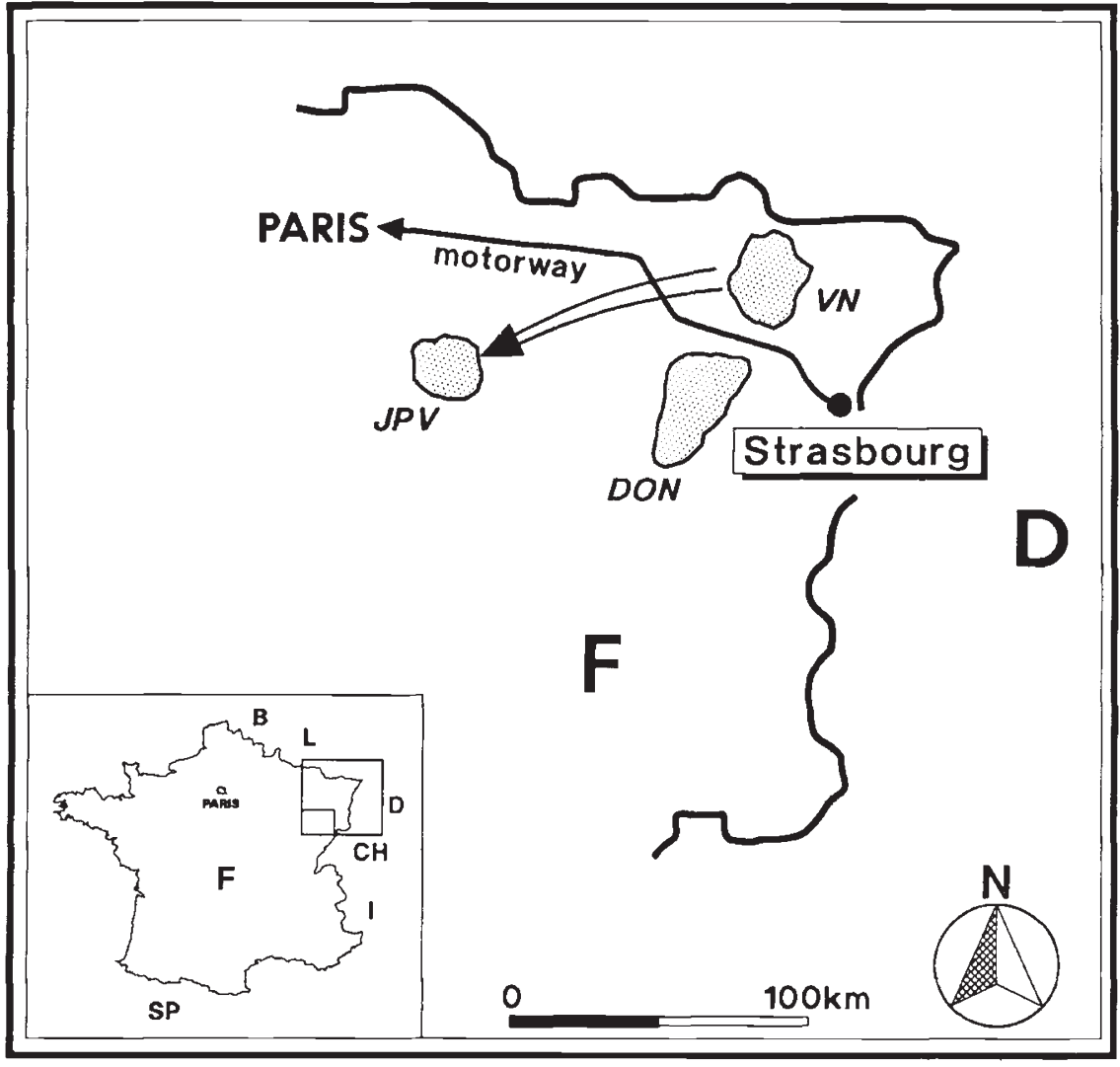

Fig. 1 Study area of red deer in eastern France (Vosges): $\mathrm{DON}=$ population in the mountain range Donon; $\mathrm{VN}=$ population in the Northern Vosges, separated from DON by the fenced motorway Paris-Strasbourg; $\mathrm{JPV}=$ population in an enclosure, animals originating from $\mathrm{VN}$. 
towards an increase in the number of points but less against small spikes.

During the hunting seasons from 1987 to 1990, liver, kidney and heart, from a total of 290 specimens (103 from DON, 155 from VN, 32 from JPV) were collected by local hunters and frozen to $-20^{\circ} \mathrm{C}$ as soon as possible after the death of the animals. Genetic variation in the respective populations was estimated by screening the following 29 isoenzyme systems using routine electrophoretic and staining techniques (Hartl \& Höger, 1986; Hartl et al., 1988b; Hartl et al., 1990. Abbreviation, E.C. number and tissue used are given in parentheses; $\mathrm{L}=$ liver, $\mathrm{K}=$ kidney, $\mathrm{H}=$ heart).

Sorbitol dehydrogenase (SDH, E.C. 1.1.1.14, L), lactate dehydrogenase (LDH, E.C. 1.1.1.27, K), malate dehydrogenase (MDH, E.C. 1.1.1.37, K), malic enzyme (ME, E.C. 1.1.1.40, K), isocitrate dehydrogenase (IDH, E.C. 1.1.1.42, K), 6-phosphogluconate dehydrogenase (PGD, E.C. 1.1.1.44, K), glucose dehydrogenase (GDH, E.C. 1.1.1.47, L), glucose-6-phosphate dehydrogenase (GPD, E.C. 1.1.1.49, K), xanthine dehydrogenase $(\mathrm{XDH}$, E.C. 1.2.3.2, L), glutamate dehydrogenase (GLUD, E.C. 1.4.1.3, L), catalase (CAT, E.C. 1.11.1.6, L), superoxide dismutase (SOD, E.C. 1.15.1.1, K), purine nucleoside phosphorylase (NP, E.C. 2.4.2.1, K), aspartate aminotransferase (AAT, E.C. 2.6.1.1, K), hexokinase (HK, E.C. 2.7.1.1, K, H), pyruvate kinase (PK, E.C. 2.7.1.40, H), creatine kinase (CK, E.C. 2.7.3.2, K, H), adenylate kinase (AK, E.C. 2.7.4.3, K, H), phosphoglucomutase (PGM, E.C. 2.7.5.1, K), esterases (ES, E.C. 3.1.1.1, K), acid phosphatase (ACP, E.C. 3.1.3.2, K), fructose-1,6diphosphatase (FDP, E.C. 3.1.3.11, L), peptidases (PEP, E.C. 3.4.11, K), aminoacylase-1 (ACY-1, E.C. 3.5.1.14, $\mathrm{K}$ ), adenosine deaminase (ADA, E.C. 3.5.4.4, $\mathrm{K}$ ), aldolase (ALDO, E.C. 4.1.2.13, H), fumarate hydratase (FH, E.C. 4.2.1.2, L), mannose phosphate isomerase (MPI, E.C. 5.3.1.8, K), glucose phosphate isomerase (GPI, E.C. 5.3.1.9, K).

The interpretation of electrophoretic band-patterns and the designation of common and variant alleles at the polymorphic loci in red deer is described in detail in Hartl et al. (1990). The proportion of polymorphic loci $(\bar{P}, 99$ per cent criterion), expected $(\bar{H})$ and observed $\left(\bar{H}_{0}\right)$ average heterozygosity were calculated according to Ayala (1982). The theoretical amount of gene flow between DON and VN was estimated using Slatkin's (1985) concept of 'private alleles' $\bar{p}(1)$ by means of the formula:

$\ln [\bar{p}(1)]=a \ln (N m)+b$

where $a=-0.505$ and $b=-2.440$ for an assumed sample size per deme of 25 . As the sample sizes of DON and VN deviate considerably from this magni- tude, the correction suggested by Slatkin (1985) and Barton \& Slatkin (1986) was applied. Furthermore, $G^{-}$ statistics (Nei, 1975) were used to estimate the number of migrating individuals $(\mathrm{Nm})$ from $F_{\mathrm{ST}}$ (in a broader sense) as outlined by Slatkin \& Barton (1989). Additional population genetic parameters, irrelevant for the present investigation, were examined in an earlier study, based on less individuals from the Vosges, but including a number of red deer populations from other parts of Europe (Hartl et al., 1990).

Morphological measurements (general body measurements and antler characters) were taken by the local hunters and the staff of ONC according to Lang (1989). The jaws were prepared from each specimen and age determination was performed by examination of growth layers in dental cement after Mitchell (1963).

The genotypes at the polymorphic enzyme loci were examined for an association with one or more of the artificial selection criteria mentioned above using samples of the respective age classes in each sex (1 year for spikes, $\geqslant 4$ years for hind foot length as an indicator for body size, $\geqslant 4$ years for number of antler points in males). The length of the main beam in antlers of stags $\geqslant 6$ years and asymmetry in length and diameter of the main beam, length of the brow tine and number of the antler points are not considered that much by selective hunting, but are included in the present study. The percentage asymmetry $(A)$ was estimated using the respective values for each character from each side of the antlers by means of the following equation (Smith et al., 1983):

$A=\frac{\mid \text { right }- \text { left } \mid}{(\text { right }+ \text { left }) / 2} \times 100$.

The associations found were examined for significance by the $t$-test, when a normal distribution of morphological character states was to be expected; otherwise the Kruskal-Wallis test was used. Differences in allele frequencies between various samples were examined for significance by means of the Chi-square test (with Yates correction in the case of less than 40 specimens available in the respective sample).

\section{Results}

With the exception of $M e-2$ and the allele $M e-1^{90}$ all isoenzyme loci found to be polymorphic in the present study (Me-1 Me-2 Idh-2 Sod-2 Pgm-2 Acp-1 Acp-2) were already described with the corresponding alleles by Hartl et al. (1990). The allele frequencies in the whole sample from each population studied are given in Table 1 . Values of polymorphism, single locus and average heterozygosity are given in Table 2 . The 
Table 1 Allele frequencies in the red deer populations studied

\begin{tabular}{lrllllll}
\hline Locus & Allele & DON & $n$ & VN & $n$ & JPV & $n$ \\
\hline Me-1 & 100 & 0.981 & 103 & 0.981 & 155 & 0.922 & 32 \\
& 125 & 0.010 & & 0.003 & & 0.016 & \\
& 90 & 0.009 & & 0.016 & & 0.062 & \\
Me-2 & 100 & 0.719 & 48 & 0.667 & 69 & 0.833 & 15 \\
& 110 & 0.281 & & 0.333 & & 0.167 & \\
Idh-2 & 100 & 0.544 & 103 & 0.403 & 155 & 0.266 & 32 \\
& 112 & 0.0 & & 0.045 & & 0.0 & \\
& 125 & 0.456 & & 0.552 & & 0.734 & \\
Sod-2 & -100 & 0.971 & 103 & 0.974 & 155 & 0.969 & 32 \\
& -200 & 0.029 & & 0.026 & & 0.031 & \\
Pgm-2 & 100 & 0.976 & 103 & 0.984 & 155 & 1.0 & 32 \\
& 89 & 0.005 & & 0.016 & & 0.0 & \\
& 79 & 0.019 & & 0.0 & & 0.0 & \\
Acp-1 & 100 & 0.820 & 89 & 0.739 & 138 & 0.826 & 23 \\
& 300 & 0.180 & & 0.261 & & 0.174 & \\
Acp-2 & 100 & 0.559 & 102 & 0.533 & 150 & 0.629 & 31 \\
& 85 & 0.441 & & 0.467 & & 0.371 & \\
\hline
\end{tabular}

number of migrating individuals per generation, calculated from $\bar{p}(\mathbf{1})$, is 1.4 ; that obtained from $G_{S T}$ is 125 .

In Me-2, Pgm-2 and Sod-2 no associations with the development of the morphological characters in

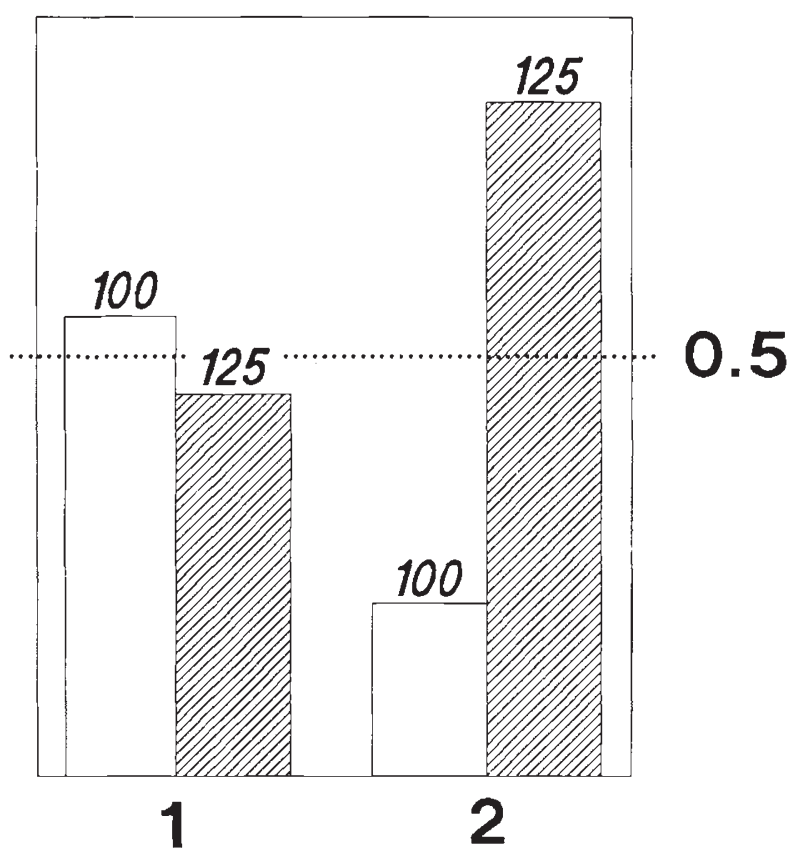

Fig. 2 Frequencies of $I d h$ - 2 alleles in different groups of male red deer. (1) among stags $\geqslant 4$ years $(n=22)$ with 6-8 antler points. ( 2 ) among stags $\geqslant 4$ years $(n=12)$ with $\geqslant 11$ antler points.
Table 2 Genetic variation in the red deer populations studied. $H\left(H_{0}\right)=$ expected (observed) heterozygosity, $\bar{H}\left(\bar{H}_{0}\right)=$ expected (observed) average heterozygosity, $\bar{P}=$ proportion of polymorphic loci $(99$ per cent criterion $)$

\begin{tabular}{ccccccc}
\hline Locus & DON & $n$ & VN & $n$ & JPV & $n$ \\
\hline Me-I & & & & & & \\
$H$ & 0.038 & 103 & 0.037 & 155 & 0.146 & 32 \\
$H_{0}$ & 0.039 & & 0.039 & & 0.156 & \\
$M e-2$ & & & & & & \\
$H$ & 0.404 & 48 & 0.444 & 69 & 0.278 & 15 \\
$H_{0}$ & 0.313 & & 0.521 & & 0.333 & \\
Idh-2 & & & & & & \\
$H$ & 0.496 & 103 & 0.531 & 155 & 0.391 & 32 \\
$H_{0}$ & 0.563 & & 0.413 & & 0.344 & \\
Sod-2 & & & & & & \\
$H$ & 0.056 & 103 & 0.051 & 155 & 0.060 & 32 \\
$H_{0}$ & 0.058 & & 0.052 & & 0.063 & \\
Pgm-2 & & & & & & \\
$H$ & 0.047 & 103 & 0.032 & 155 & 0.0 & 32 \\
$H_{0}$ & 0.049 & & 0.032 & & 0.0 & \\
Acp-1 & & & & & & \\
$H^{\prime}$ & 0.295 & 89 & 0.386 & 138 & 0.287 & 23 \\
$H_{0}$ & 0.337 & & 0.406 & & 0.348 & \\
Acp-2 & & & & & & \\
$H$ & 0.493 & 102 & 0.498 & 150 & 0.467 & 31 \\
$H_{0}$ & 0.333 & & 0.387 & & 0.345 & \\
$\tilde{H}$ & 0.043 & & 0.046 & & 0.038 & \\
$\tilde{H}_{0}$ & 0.039 & & 0.043 & & 0.037 & \\
$\bar{P}$ & 0.163 & & 0.163 & & 0.140 & \\
\hline
\end{tabular}

question were detected. In $I d h-2$, the allele $I d h-2^{I 25}$, occurring in homozygous condition, is positively associated with hind foot length in females $(n=27$, the difference in mean hind foot length of $I d h-2^{I 25}$ and $I d h-2^{100}$ or $I d h-2^{100 / 125}$ carriers $=27.2 \mathrm{~mm}, P<0.001$, $t$-test $)$ and the number of antler points in males $(n=46$, the difference in mean number of antler points $=1.58$, $P<0.05$, Kruskal-Wallis test). The frequency of the allele $I d h-2^{125}$ in relation to $I d h-2^{100}$ among males with $6-8$ points and males with $\geqslant 11$ points is shown in Fig. 2 . The difference in allele frequencies between both groups is statistically significant at $P<0.01$ (Chi-square test). As there is a marked difference in the mean numbers of antler points already among young stags $\left(1.78\right.$ between $I d h-2^{I 25}$ and $I d h-2^{l 09}$ or $I d h-2^{100 / 125}$ carriers $\geqslant 2$ years is significant at $P<0.02,2.05$ in stags $\geqslant 3$ years at $P<0.01, t$-test $)$, this result indicates a generally more rapid antler development in the $I d h$ $2^{225}$ carriers.

In order to test, whether differences in allele frequencies of VN and JPV in relation to DON (Fig. 3) can be explained by selection (hunting) rather than by 
Fig. 3 Frequencies of $I d h$-2 alleles among females and calves in the populations $\mathrm{DON}(1), \mathrm{VN}(2)$ and JPV (3).

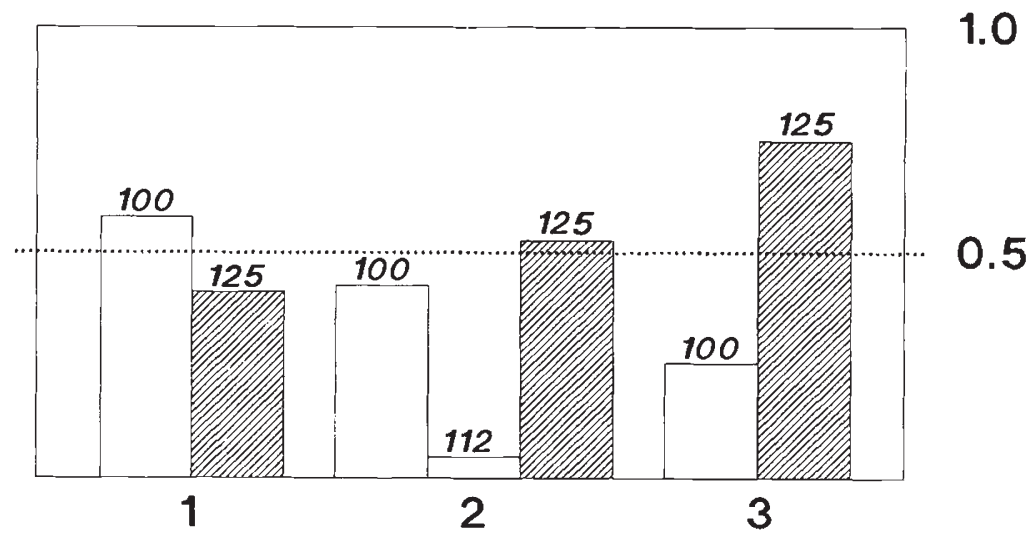

Table 3 Allele frequencies in females and calves of the red deer populations studied (control group), culled without selection

\begin{tabular}{lrllllll}
\hline Locus & Allele & DON & $n$ & VN & $n$ & JPV & $n$ \\
\hline Me-1 & 100 & 1.0 & 48 & 0.983 & 116 & 1.0 & 8 \\
& 125 & 0.0 & & 0.000 & & 0.0 & \\
& 90 & 0.0 & & 0.017 & & 0.0 & \\
Me-2 & 100 & 0.750 & 22 & 0.641 & 46 & 0.667 & 3 \\
& 110 & 0.250 & & 0.359 & & 0.333 & \\
Idh-2 & 100 & 0.583 & 48 & 0.427 & 117 & 0.250 & 8 \\
& 112 & 0.0 & & 0.043 & & 0.0 & \\
& 125 & 0.417 & & 0.530 & & 0.750 & \\
Sod-2 & -100 & 1.0 & 48 & 0.983 & 117 & 1.0 & 8 \\
& -200 & 0.0 & & 0.017 & & 0.0 & \\
Pgm-2 & 100 & 0.990 & 48 & 0.992 & 117 & 1.0 & 8 \\
& 89 & 0.0 & & 0.008 & & 0.0 & \\
& 79 & 0.010 & & 0.0 & & 0.0 & \\
Acp-1 & 100 & 0.825 & 40 & 0.723 & 103 & 0.833 & 6 \\
& 300 & 0.175 & & 0.277 & & 0.167 & \\
Acp-2 & 100 & 0.649 & 47 & 0.535 & 113 & 0.571 & 7 \\
& 85 & 0.351 & & 0.465 & & 0.429 & \\
\hline
\end{tabular}

average heterozygosity or enzyme genotypes and asymmetry in the length and diameter of the main beam, length of the brow tine and the number of antler points.

\section{Discussion}

The values of polymorphism and heterozygosity are similar to those detected by Hartl et al. (1990). Due to the increased sample sizes of individuals, however, a third rare allele at the $M e-1$ locus was detected. Furthermore, whereas ME-2 could not be consistently 
scored in the former study, two allozymes were clearly distinguishable in the present material.

Whereas the number of migrating individuals per generation $(N m)$ is rather high according to the estimate derived from $G_{\mathrm{ST}}$, it is considerably lower when derived from $\bar{p}(1)$. In addition, the latter value would indicate some gene flow but the very short time passed since the isolation of the $\mathrm{VN}$ population from DON must be considered. As Pgm- ${ }^{79}$ was detected only in DON and $I d h-2^{l 12}$ only in $\mathrm{VN}$, rare alleles appear to give more information about short-term isolation of the respective populations than overall relative differentiation $\left(G_{\mathrm{ST}}=0.002\right)$. The latter measurement is based on differences between the expected average heterozygosity of a fictive total population and the mean $\bar{H}$ of the respective subpopulations, which may need a longer time span for accumulation (rare alleles do not count at all in this approach).

Concerning the preferential associations of enzyme alleles with a particular development of morphological characters reported in this paper, the majority were already tested and found to be significant when less specimens were available. Furthermore, we concentrated on the characters considered by selective hunting, with only a few additions. This is particularly noteworthy, because when a number of correlations are performed, some may become significant simply by chance and the change in allele frequencies from DON to $\mathrm{VN}$ and from VN to JPV (although the sample size of females and calves is small in this population) supports the validity of the associations described.

In $I d h-2^{125}$ the change in allele frequencies would also be unexplainable by genetic drift, when a sex ratio in reproduction of $1 \mathrm{~m}$ :(up to) $8 \mathrm{f}$ is assumed, which is very unlikely. Such an unequal sex ratio would lead to a smaller $N_{\mathrm{e}}$ and, thus, to an increase in genetic drift and an upper bound of the $I d h-2^{125}$ frequency to be reached of 0.508 . In JPV the frequency of $I d h-2^{I 25}$ with 0.750 (Table 3 ) is slightly higher than the maximum value to be reached by drift (upper bound $=0.744$ ). Together with the occurrence of higher numbers of antler points in $\mathrm{VN}$ (in 1977 8-20 per cent, in 1986 30-40 per cent of stags $\geqslant 5$ years old with double crown; in total 52-58 per cent of stags $\geqslant 5$ years old with single or double crown: Klein, 1987) and especially in JPV (75-80 per cent of stags $\geqslant 5$ years old with single or double crown: J. P. Villenave, head of the enclosure, personal communication), these results indicate that the frequency of $I d h-2^{I 25}$ was increased by selective hunting rather than by genetic drift.

Previous results of Pemberton et al. (1988), in Scottish red deer from the island of Rhum, suggests that natural selection favours heterozygotes of
$I d h-2^{100 / 125}$ by a better viability of heterozygous female calves. An excess of heterozygotes among adult females in relation to calves could not be detected in our data but this difference can be explained by the fact that natural mortality on Rhum is high because of high population density and limited food availability (Lowe, 1969; Pemberton et al., 1988). In our populations, however, with lower density, sufficient trophic resources and high hunting pressure, natural mortality is likely to be much less important. As already emphasized by Pemberton et al. (1988), at present it cannot be decided whether selection is associated with the physiological properties of enzyme variants or with the close linkage of an enzyme locus with a gene or gene complex being responsible for the development of the morphological characters in question. So our data would fit, for example, to a linkage with a 'single major gene' which affects the expression of antler point number as described in the white-tailed deer by Templeton et al. (1983).

In addition, the allele frequency change of $A c p-I^{100}$ from DON to $\mathrm{VN}$ cannot be explained by genetic drift; neither with a sex ratio of $1 \mathrm{~m}: 2 \mathrm{f}$ nor with a sex ratio of $1 \mathrm{~m}$ :(up to) $8 \mathrm{f}$. It can, however, be explained by the strong hunting pressure against small spikes. In $M e-1^{90}$ the strong association with small spikes indicates that further heavy hunting pressure against carriers of this trait could lead towards a total elimination of the allele from the population. The artificial selection against small spikes in VN seems to be particularly effective, as the hunting criterion is simple, the yearlings are not shy, and, as a motivation for selective culling, hunters are rewarded for killing a 'bad' yearling by obtaining permission to shoot another individual.

As in $I d h-2^{125}$ and $A c p-1^{100}$, the change in the Acp$2^{100}$ frequency from DON to $\mathrm{VN}$ cannot be explained by genetic drift alone. However, because the associated length of the main beam is not directly affected by selective hunting, a straightforward interpretation of this result is not possible.

In remarkable contrast to the white-tailed deer, no association could be detected between the average heterozygosity and the development or the degree of asymmetry of the morphological characters studied (see Smith et al., 1983; Scribner et al., 1989). It must be noted, however, that the extent of enzyme variation in the white-tailed deer is by far the highest among all deer species yet studied, both with respect to the number of loci polymorphic and the number of alleles found (see Hartl \& Reimoser, 1988; Hartl et al., 1990, for reviews). A possible difference in the significance of enzyme polymorphism between $r$-(white-tailed) and $K$ strategist (red) deer species has been discussed by Hartl \& Reimoser (1988). 
Altogether our results suggest that the characters investigated in the present study do not show a relationship to overall fitness as far as can be indicated by the degree of overall heterozygosity (e.g. Johns et al., 1977; Fleischer et al., 1983; Smith et al., 1983; Scribner et al., 1989). It is rather the case that alleles at certain enzyme loci are associated with a special development of morphological characters, and some of them can be lost by a consequent directional hunting pressure. This need not necessarily be reflected by a decrease in overall heterozygosity (Hartl et al., 1988a; Hartl, 1989), but it may be dangerous in intensively managed species, as the counteraction of natural selection (e.g. in favour of $I d h-2$ heterozygotes: Pemberton et al., 1988) may be suppressed.

\section{Acknowledgements}

The authors are indebted to the local hunters in the Alsace and Lorraine for collecting samples and for financial support. The excellent technical assistance of Anita Haiden and the graphical help of Andreas Körber are gratefully acknowledged.

\section{References}

AYAlA, F. J. 1982. Population and Evolutionary Genetics: A Primer. Benjamin Cummings, Menlo Park, CA.

BARTON, N. H. AND SLATKIN, M. 1986. A quasi-equilibrium theory of the distribution of rare alleles in a subdivided population. Heredity, 56, 409-415.

CLUTTON-BROCK, T. H., GUINNESS, F. E. AND ALBON, S. D. 1982. Red Deer - Behavior and Ecology of Two Sexes. University of Chicago Press, Chicago, IL.

FLEISCHER, R. C., JOHNSTON, R. F. AND KLITZ, W. J. 1983. Allozymic heterozygosity and morphological variation in house sparrows. Nature, 304, 628-630.

HARMEL, D. E. 1983. Effects of genetics on antler quality and body size in white-tailed deer. In: Brown, R. (ed.), Antler Development in Cervidae. Caesar Kleberg Foundation, Kingsville, pp. 339-348.

HARTL, G. B. 1989. Die genetische Variabilität von Wildsäugern und die Folgen der Isolation. In: Schneider, E., Oelke, H. and Gross, H. (eds), Die Illusion der Arche Noah Gefahren für die Arterhaltung durch Gefangenschaftszucht. Echo-Verlag, Göttingen, pp. 127-138.

HARTL, G. B. AND HÖGER, H. 1986. Biochemical variation in purebred and crossbred strains of domestic rabbits (Oryctolagus cuniculus L.). Genetical Research, Cambridge, 48, 27-34.

HARTL, G. B. AND REIMOSER, F. 1988. Biochemical variation in roe deer (Capreolus capreolus L.): are $r$-strategists among deer genetically less variable than $K$-strategists? Heredity, 60, 221-227.

HARTL, G. B., GOLTENBOTH, R., GRILLITSCH, M. AND WILLING, R. 1988a. On the biochemical systematics of the Bovini. Biochem. System. Ecol., 16, 575-579.
HARTL, G. B., WILLING, R., GRILLITSCH, M. AND KLANSEK, E. 1988b. Biochemical variation in Mustelidae: are carnivores genetically less variable than other mammals. Zool. Anzeiger, 22 1, 81-90.

HARTL, G. B., WILLING, R., LANG, G., KLEIN, F. AND KÖLLER, J. 1990. Genetic variability and differentiation in red deer (Cervus elaphus L.) of Central Europe. Genetics, Selection, Evolution, 22, 289-306.

JOHNS, P. E., BACCUS, R., MANLOVE, M. N., PINDER, J. E. III. AND SMTTH, M. H. 1977. Reproductive patterns, productivity and genetic variability in adjacent white-tailed deer populations. Proc. Ann. Conf. Southeastern Assoc. Fish Wildl. Agencies, 31, 167-172.

KLEIN, F. (1987). La gestion du cerf (Cervus elaphus) dans le secteur de La Petite Pierre. Ciconia, 11, 97-108.

LANG, G. 1987. Gestion des populations de cervidés réflexions sur des problemes de polymorphisme génétique. Thèse de Diplôme d'Etat de Docteur en Pharmacie, Université Louis Pasteur, Strasbourg.

LANG, G. 1989. Guidelines for the collection of morphological data in red deer. In: Hartl, G. B. (ed.), Proceedings of the 2nd Symposium for Planning a CIC Red Deer Genetics Project, pp. 24-30. Vet. Med. University, Vienna.

LOWE, V. P. W. 1969. Population dynamics of the red deer (Cervus elaphus L.) on Rhum. J. Anim. Ecol., 38, 425-457.

LuCoTte, G. 1983. Génétique des populations. Inter Editions, Paris.

MARCHINTON, R. L., FUDGE, J. R., FORTSON, J. C. AND MILLER, K. V. 1987. Genetic stock and environment as factors in production of record class antlers. In: Bobek, B., Perzanowski, K., Regelin, W. L. and Tertil, R. (eds), Abstracts of the $X$ VIIIth Congress of the International Union of Game Biologists - Supplement, Jagiellonian University, Krakow, p. 114 (comprehensive manuscript obtained from the authors).

MITCHELL, B. 1963. Determination of age in Scottish red deer from growth layers in dental cement. Nature, 198, $350-351$.

NEI, M. 1975. Molecular Population Genetics and Evolution. Elsevier/North Holland, Amsterdam.

PEMBERTON, J. M., ALBON, S. D., GUINNESS, F. E. AND CLUTTONBROCK, T. H. 1988. Genetic variation and juvenile survival in red deer. Evolution, 42, 921-934.

RøED, K. H. 1987. Transferrin variation and body size in reindeer, Rangifer tarandus L. Hereditas, 106, 67-71.

RYMAN, N., BACCUS, R., REUTERWALL, C. AND SMITH, M. H. 1981. Effective population size, generation interval and potential loss of genetic variability in game species under different hunting regimes. Oikos, 36, 257-266.

SCHONEWALD-COX, C. M., CHAMBERS, S. M., MACBRYDE, B. AND THOMAs, w. L. (eds) 1983. Genetics and Conservation. Benjamin Cummings, London.

SCRIBNER, K. T., SMITH, M. H. AND JOHNS, P. E. 1989. Environmental and genetic components of antler growth in whitetailed deer. J. Mammal., 70, 284-291.

SLATKIN, M. 1985. Rare alleles as indicators of gene flow. Evolution, 39, 53-65.

SLATKIN, M. AND BARTON, N. H. 1989. A comparison of three 
indirect methods for estimating average levels of gene flow. Evolution, 43, 1349-1368.

SMITH, M. H., CHESSER, R. K., COTHRAN, E. G. AND JOHNS, P. E. 1983. Genetic variability and antler growth in a natural population of white-tailed deer. In: Brown, R. (ed.), Antler Development in Cervidae. Caesar Kleberg Foundation, Kingsville, pp. 365-387.

SOULE, M. E. 1979. Heterozygosity and developmental stability: another look. Evolution, 33, 396-401.

SOULE, M. E. (ed.) 1987. Viable Populations for Conservation. Cambridge University Press, Cambridge.

SUTTIE, J. M. AND KAY, R. N. B. 1983. The influence of nutrition and photoperiod on the growth of antlers of young red deer. In: Brown, R. (ed.), Antler Development in Cervidae. Caesar Kleberg Foundation, Kingsville, pp. 61-71.

TEMPLETON, J. W., SHARP, R. M., WILLIAMS, J., DAVIS, D., HARMEL, D., ARMSTRONG, B. AND WARDROUP, S. 1983. Single dominant major gene effect on the expression of antler point number in the white-tailed deer. In: Brown, R. (ed.), Antler Development in Cervidae. Caesar Kleberg Foundation, Kingsville, p. 469.

ueCKermann, E. (1987) Managing German red deer (Cervus elaphus L.) populations. In: Wemmer, C. (ed.), Biology and Management of the Cervidae. Smithsonian Institution Press, Washington/DC, pp. 505-516.

wATT, w. B. 1985. Bioenergetics and evolutionary genetics: opportunities for new synthesis. Am. Nat., 125, 118-143.

WILLIAMS, J. D., HARMEL, D. E., ARMSTRONG, W. E. AND WARDROUP, S. E. 1983. Antler development in the white-tailed deer. In: Brown, R. (ed.), Antler Development in Cervidae. Caesar Kleberg Foundation, Kingsville, p. 468.

ZOUROS, E., ROMERO-DOREY, M. AND MALLET, A. L. 1988. Heterozygosity and growth in marine bivalves: further data and possible explanations. Evolution, 42, 1332-1341. 